\title{
Corrosion effect of microorganisms and their metabolite on cement mortar lined pipelines in reclaimed water distribution systems
}

\author{
Fan $\mathrm{YANG}^{1 *}$, Minning $\mathrm{CHEN}^{1}$ \\ ${ }^{1}$ College of Engineering and Technology, Tianjin Agricultural University, 22, Jinjing Road, Tianjin300384, China
}

\begin{abstract}
The reclaimed water containing high salinity, great amounts of organic matters and high nutrients can easily lead to growth of biofilms in reclaimed water distribution systems (RWDSs). The microbes colonize the cement surface and microbial metabolites can cause cement biodeterioration. To understand the effect of microbial involvement in the degradation, this study investigated the transformation characteristics of cement-mortar lining and microbial biomass in the simulated RWDS for 1 year by X-ray diffractometer (XRD), X-Ray Fluorescenc (XRF), Heterophic bacteria count (HPC) and DAPI staining. Microbial metabolites were analyzed by GC/MS. The result shows that the carbonation reaction took place in the surface of the eroded cement-mortar lining where the content of $\mathrm{CaCO}_{3}$ was continuously increasing while the content of hydrated compounds were decreasing. The depositing layer of $\mathrm{CaSO}_{4} \cdot 2 \mathrm{H}_{2} \mathrm{O}$, $\mathrm{CaAl}_{2} \mathrm{Si}_{2} \mathrm{O}_{8} \cdot 4 \mathrm{H}_{2} \mathrm{O}$ and $\mathrm{Mg}_{4} \mathrm{Al}_{2}(\mathrm{OH})_{14} \cdot 3 \mathrm{H}_{2} \mathrm{O}$ on the lining surface were formed by minerals such as $\mathrm{Ca}, \mathrm{Si}$, $\mathrm{Al}$ and $\mathrm{Mg}$ lost from the degraded hydrated compounds. Microbial biomass in the RWDS has maintained an increasing trend during the study. The main microbial metabolites of the biofilm on the cement surface are fatty acids, amino acids, and carbohydrate.
\end{abstract}

\section{Introduction}

The utilization of reclaimed water is an effective ways to alleviate water resources shortage, reduce pollution load of urban water environment, improve the ecological environment. The ductile iron pipe with cement-mortar lining are widely used in the reclaimed water distribution systems (RWDSs) because of its cost-effective, stable mechanical property and durability. Although the reclaimed water meets the regulatory standards, a large amount of organic matters and inorganic ions in reclaimed water can cause microorganism regrowth, biofilm induced corrosion and water quality changes during transport through the distribution system to the use point [1-4].

Cement hydration products $\mathrm{Ca}(\mathrm{OH})_{2}, \mathrm{C}_{3} \mathrm{~S}, \mathrm{C}_{2} \mathrm{~S}, \mathrm{C}_{3} \mathrm{~A}$ and calcium silicate hydrates (CSH) can be stable in the high alkaline environment $(\mathrm{pH}$ 12.5-13.5). When the cement-mortar is immersed in the reclaimed water, erosion media such as $\mathrm{CO}_{2}$, sulfate and chloride ion may all reacted with cement hydration products by diffusing into the pores of cement-mortar lining. Carbonic aggressivity is one type of interaction with water concerns the calcium carbonate saturation state and carbonate speciation of the water, which can lead to the rapid degradation of the cement material(eq.1-2). High sulfate reacts with $\mathrm{Ca}(\mathrm{OH})_{2}$ in the cement-mortar lining to form gypsum (eq.3) which can cause internal expansion and softening $[5,6]$.The microbes colonized on the concrete surface and in its pores, capillaries and micro-cracks cause damage through biodeterioration, such as sulphur bacteria, nitrifying bacteria, acid producing fungus and their microbial metabolites. Sulfur-oxidizing bacteria produce biogenic sulfuric acid which can react with the $\mathrm{Ca}(\mathrm{OH})_{2}$ in the cement-mortar lining to form gypsum (eq.4, 5). Microbial metabolites like organic acid, carbon dioxide, mineral acids like sulfuric acid and nitric acid all can cause biodeterioration by reacting with the components of cement (eq.6) [7].

$$
\begin{aligned}
& \mathrm{Ca}(\mathrm{OH})_{2}+\mathrm{CO}_{2} \longrightarrow \mathrm{CaCO}_{3}+\mathrm{H}_{2} \mathrm{O} \\
& \mathrm{CaCO}+\mathrm{CO}_{2}+\mathrm{H}_{2} \mathrm{O} \longrightarrow \mathrm{Ca}\left(\mathrm{HCO}_{3}\right)_{2} \\
& \mathrm{Ca}(\mathrm{OH})_{2}+\mathrm{Na}_{2} \mathrm{SO}_{4}+2 \mathrm{H}_{2} \mathrm{O} \longrightarrow \\
& \mathrm{CaSO}_{4} \cdot 2 \mathrm{H}_{2} \mathrm{O}+2 \mathrm{Na}^{+}+2 \mathrm{OH}^{-} \\
& \quad \mathrm{H}_{2} \mathrm{~S}+2 \mathrm{O}_{2} \longrightarrow \mathrm{H}_{2} \mathrm{SO}_{4} \\
& \mathrm{Ca}(\mathrm{OH})_{2}+\mathrm{H}_{2} \mathrm{SO}_{4} \longrightarrow \mathrm{CaSO}_{4} \cdot 2 \mathrm{H}_{2} \mathrm{O}(\text { gypsum }) \\
& \mathrm{Ca}(\mathrm{OH})_{2}+2 \mathrm{C}_{2} \mathrm{H}_{4}(\mathrm{OH}) \mathrm{COOH}_{3} \mathrm{H}_{2} \mathrm{O} \longrightarrow \\
& \mathrm{Ca}\left[\mathrm{C}_{2} \mathrm{H}_{4}(\mathrm{OH}) \mathrm{COO}\right]_{2} \cdot 5 \mathrm{H}_{2} \mathrm{O}
\end{aligned}
$$

Yang et al. have found that reclaimed water had carbonic aggressivity to the cement-mortar liner, and the erosion products on the lining surface can not form a effective protective layer [8]. Jin et al. extracted extracellular polymeric substances (EPS) on biofilm in a reclaimed water distribution system from different culturing stages contained different proportions of

\footnotetext{
* Corresponding author:fanyang20062800@163.com
} 
protein and polysaccharide with similar functional groups. Excessive amount of EPS promoted anodic dissolution through EPS-Fe binding to accelerate the pipe corrosion [9]. In this study, the erosion process of micro-organisms and their metabolites on cement-mortar liner in a simulated RWDS was investigated. The changes of physicochemical characteristics of eroded cement-mortar lining were studied by XRD and XRF and the microbial biomass in RWDS was regularly monitored. Combined with the above results, the microbial metabolites were analyzed to reveal the chemical and microbiological erosion of cement lining in RWDS.

\section{Materials and methods}

\subsection{Pipe loop set-up and experimental operation}

The simulated reclaimed water distribution system consists of three lm-length DN100 new cement mortar lined ductile iron pipe sections, the water tank, metering pump and flow meter connected by PVC plastic pipe (DN20) to form a recirculating pipe rig system (Figure 1). Five $5 \mathrm{~cm}$-length DN100 new cement-mortar lined ductile iron pipe sections (referred to as "tested coupon") (shown in Figure 1) are also placed in the pipe loop system to provide cement-mortar samples and biofilm samples for subsequent tests. Reclaimed water was circulated from the water tank to testing loops using a metering pump at flow rate of $10 \mathrm{~L} \cdot \mathrm{h}^{-1}$ with the hydraulic retention time $48 \mathrm{~h}$. There were no disinfectant added during the experimental period.

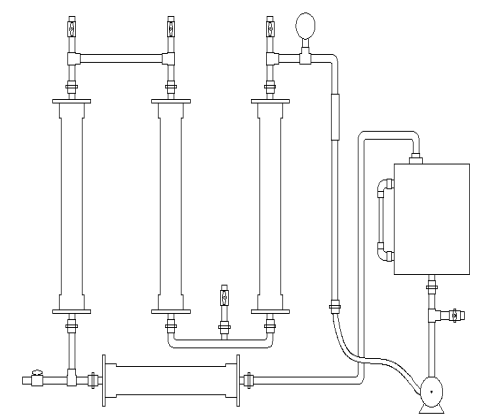

Fig.1. Simulated reclaimed water distribution system used for experiment

\subsection{Analytical methods and Reagents}

Water quality was measured according to Standard Methods [10]. The $\mathrm{pH}, \mathrm{DO}$ and conductivity were measured using Portable Multiparameter meter (Sension156 HACH, USA) and the turbidity was measured using a 2100P Turbidimeter (HACH, USA). The $\mathrm{BOD}_{5}$ was measured using a Biochemical Oxygen Demand Trak II Analyzer (HACH, USA). The CODcr, $\mathrm{TN}$, Ammonia-N, TP and Residual chlorine were measured using using HACH DR2800 spectrophotometer. Alkalinity and total hardness were measured by chemical titration. The sulfate and chloride were analyzed by Ion Chromatography System-1000 (Dionex,
USA). The total iron and $\mathrm{SiO}_{2}$ were analyzed by the Inductively Coupled Plasma Optical Emission Spectrometer (Perkin-Elmer Optima 2000, USA). As the reclaimed water in system was replaced every two weeks, sampling for water quality analysis was performed at one time per week with three parallel samples and the water parameter values were the average values of the three parallel samples.

Table 1. Water quality parameters of reclaimed water (units: conductivity in $\mu \mathrm{s} \cdot \mathrm{cm}^{-1}$, alkalinity in $\mathrm{mg} \cdot \mathrm{L}^{-1}$ as $\mathrm{CaCO}_{3}$, others in $\mathrm{mg} \cdot \mathrm{L}^{-1}$ )

\begin{tabular}{|c|c|c|c|}
\hline pH & DO & Conductivity & Turbidity \\
\hline 6.95 & 7.04 & 891.50 & 0.34 \\
\hline $\mathrm{BOD}_{5}$ & $\mathrm{COD}_{\mathrm{Cr}}$ & $\begin{array}{c}\text { Total } \\
\text { Nitrogen }\end{array}$ & $\begin{array}{l}\text { Ammonia } \\
\text { Nitrogen }\end{array}$ \\
\hline 2.15 & 14.95 & 14.60 & 2.38 \\
\hline $\begin{array}{c}\text { Total } \\
\text { Phosphoru } \\
\text { S }\end{array}$ & $\begin{array}{l}\text { Residual } \\
\text { Chlorine }\end{array}$ & Alkalinity & $\begin{array}{c}\text { Total } \\
\text { Hardness }\end{array}$ \\
\hline 0.26 & 0.70 & 108.20 & 243.45 \\
\hline Sulfate & Chloride & Total Iron & $\mathrm{SiO}_{2}$ \\
\hline 211.55 & 239 & $<0.016$ & 1.19 \\
\hline
\end{tabular}

\subsection{Experimental water}

The reclaimed water used in the system was taken from a water reclamation plant in an northern city of China from December 2014 to December 2015. The average values of the monitored parameters biweekly were summarized in Table 1. Water quality parameters of reclaimed water which contained high levels of conductivity, hardness, inorganic ions and organic matter were inferior to tap water.

\subsection{Physicochemical characterization of cement mortar lining composition analysis}

Cement-mortar lining samples collected from the pipe coupons connected in pipe loop systems were pretreated for X-ray diffraction (XRD) and X-ray Fluorescence (XRF), as soon as possible. The pretreatment procedures were as follows: samples scraped from the pipe coupons were pulverized in an agate mortar and passed through a $150 \mu \mathrm{m}$ mesh sieve, then vacuum-freeze-dried. The surface layer sample (SL) of cement-mortar liner was the top layer with $2-3 \mathrm{~mm}$ thickness scraped off by a spatula and the rest of cement-mortar liner was the inner layer $\mathrm{s}$ amples (IL). The XRD (D/max-rA, Rigaku, USA) operation parameters were: $\mathrm{Cu} \mathrm{K} \alpha$ radiation at $40 \mathrm{KV}$ and $100 \mathrm{~mA}$, the $2 \mathrm{\theta}$ ranged from $3^{\circ} \mathrm{C}$ to $70^{\circ} \mathrm{C}$ with a $0.02^{\circ} \mathrm{C}$ step, and a $0.15 \mathrm{~s}$ count time at each step. Crystalline phase was identified using the Jade XRD software, and crystalline phase composition of the cement-mortar liner was quantitatively determined by contrasted parameters of intensity method [11]. The elemental composition of cement-mortar liner samples was determined by XRF (Advant' XP, Thermo Electron, Switzerland). The XRF spectrometer with a Lawrencium 
(Lr) excitation tube was employed with voltage of 0-70 $\mathrm{KV}$, and with current of $0-120 \mathrm{~mA}$.

\subsection{Microbial biomass analysis}

Heterotrophic plate counts (HPC) and total DAPI counts were used to enumerate cells on the cement-mortar liner surface at different experimental period in the system. For enumeration by HPCs (CFU/L), bacteria were collected by filtration on $0.45-\mu \mathrm{m}$ porosity, $45-\mathrm{mm}$ diameter, acetated cellulose filters. The filters were placed on $\mathrm{R}_{2} \mathrm{~A}$ agar plates for cultivation and incubated for 7 days at $22 \pm 2^{\circ} \mathrm{C}$. Duplicate counts were performed through single-plate dilution for each measurement [12]. Biomass samples were washed twice and diluted $\left(10^{-3}\right.$ or $10^{-4}$ ) in PBS medium, vortexed and homo-genized. Suspensions were then filtered using $0.2 \mathrm{~mm}$ pore-size black polycarbonate membrane filters. The cells were then fixed in the dark by dipping the filter into a $4 \%$ formaldehyde solution for $2-3 \mathrm{~h}$ at room temperature, briefly washed with sterile deionized water, and air-dried in the dark. Filter were then placed on a glass slide and stained with $60-\mathrm{ml}$ of a DAPI solution $\left(1 \mathrm{mg} \cdot \mathrm{ml}^{-1}\right.$ in distilled water) for $5 \mathrm{~min}$ at room temperature in the dark [13]. Washed and air-dried filters were mounted on a glass slide with an anti-fading mounting medium (Vectashield H-1000) and examined using an epifluorescence microscope (BX60; Olympus) equipped with $a \times 100$ objective lens and a set of DAPI-specific filters (ref. U-MWU, Olympus: Dichroic Mirror 400nm, BandPass330-385nm, and Barrier 420nm). The procedure was applied to duplicate samples.

\subsection{Microbial metabolites extraction}

Fresh biofilm sample scraped from cement-mortar liner under aseptic conditions was immersed in an appropriate amount of PBS solution, and well-dispersed by sonicator. The biofilm solution was centrifuged at $12000 \mathrm{rpm}$ for 10 minutes, $4^{\circ} \mathrm{C}$. With supernatant liquid removed, the residue and the indicated amount of cation exchange resin (DOWEX 50X8, 20-50 mesh, Fluka 44445) were incubated in oscillator and stirred for $2 \mathrm{~h}$ at $4^{\circ} \mathrm{C}$. The cation exchange resin was pre-washed in extraction buffer $\left(2 \mathrm{mM} \mathrm{Na}_{3} \mathrm{PO}_{4}, 4 \mathrm{mM} \mathrm{NaH} \mathrm{PO}_{4}, 9 \mathrm{mM} \mathrm{NaCl}\right.$, $1 \mathrm{mM} \mathrm{KCl}, \mathrm{pH} 7.0 ; 1 \mathrm{~kg}$ DOWEX in $2 \mathrm{~L}$ extraction buffer, $1 \mathrm{~h}$ with stirring). Then the mixture was centrifuged at 12000 rpm for 10 minutes $4^{\circ} \mathrm{C}$ and the supernatants were metabolites for analysis [14].

Table 2. Relative percentages of the crystal material of cement lining test slice based on X-ray diffraction measurement.

\begin{tabular}{|c|c|c|c|c|c|c|c|c|c|}
\hline Sample Name & $\mathrm{CaCO}_{3}$ & $\begin{array}{c}\mathrm{Ca}(\mathrm{O} \\
\mathrm{H})_{2}\end{array}$ & $\begin{array}{l}\mathrm{C}_{3} \\
\mathrm{~S}\end{array}$ & $\mathrm{C}_{2} \mathrm{~S}$ & $\begin{array}{r}\mathrm{Ca}_{2}( \\
\mathrm{Cl}_{2} \mathbf{F e} \\
+3\}_{2}\end{array}$ & $\mathrm{C}_{3} \mathrm{~A}$ & $\underset{2 \mathrm{O}}{\mathrm{CaSO}_{4} \cdot 2 \mathrm{H}}$ & $\begin{array}{c}\mathrm{CaAl}_{2} \mathrm{Si}_{2} \mathrm{O} \\
8 \cdot 4 \mathrm{H}_{2} \mathrm{O}\end{array}$ & $\begin{array}{l}\mathrm{Mg}_{4} \mathrm{Al}_{2}(\mathrm{O} \\
\mathbf{H})_{14} \cdot 3 \mathrm{H}_{2} \mathrm{O}\end{array}$ \\
\hline IL sample $0 \mathrm{~d}$ & $39.2 \%$ & $\begin{array}{c}13.7 \\
\%\end{array}$ & $\begin{array}{l}15 . \\
7 \%\end{array}$ & $7.9 \%$ & $\begin{array}{c}13.7 \\
\%\end{array}$ & $9.8 \%$ & $0 \%$ & $0 \%$ & $0 \%$ \\
\hline $\begin{array}{c}\text { white } \\
\text { insoluble remainder on } \\
\text { the surface-296d }\end{array}$ & $0 \%$ & $0 \%$ & $0 \%$ & $0 \%$ & $0 \%$ & $0 \%$ & $16 \%$ & $49 \%$ & $36 \%$ \\
\hline SL sample-296d & $100 \%$ & $0 \%$ & $0 \%$ & $0 \%$ & $0 \%$ & $0 \%$ & $0 \%$ & $0 \%$ & $0 \%$ \\
\hline IL sample-296d & $38 \%$ & $12 \%$ & $\begin{array}{l}50 \\
\%\end{array}$ & $0 \%$ & $0 \%$ & $0 \%$ & $0 \%$ & $0 \%$ & $0 \%$ \\
\hline SL sample-564 d & $100 \%$ & $0 \%$ & $0 \%$ & $0 \%$ & $0 \%$ & $0 \%$ & $0 \%$ & $0 \%$ & $0 \%$ \\
\hline IL sample-564d & $81 \%$ & $9 \%$ & $\begin{array}{l}10 \\
\%\end{array}$ & $0 \%$ & $0 \%$ & $0 \%$ & $0 \%$ & $0 \%$ & $0 \%$ \\
\hline
\end{tabular}

\subsection{Metabolomic GC/MS analysis}

An Agilent7890A/5975C GC-MS chromatograph with a 30m HP-5MS capillary column, i.d. $250 \mu \mathrm{m}$, film thickness (df) $0.25 \mu \mathrm{m}$ separation column was used for analysis of microbial metabolites. All injections were performed in split less mode with $1.0 \mu$ l volume; the oven was held at an initial temperature of $80^{\circ} \mathrm{C}$ for $2.0 \mathrm{~min}$ before increasing to $300^{\circ} \mathrm{C}$ at $10^{\circ} \mathrm{C} \mathrm{min}^{-1}$; the final temperature was held for $6.0 \mathrm{~min}$. The transfer line was held at $280^{\circ} \mathrm{C}$ and the detector voltage at $-1624 \mathrm{~V}$. Mass spectra were acquired from 35 to $780 \mathrm{~m} / \mathrm{z}$, at an acquisition frequency of 4 spectra $\mathrm{s}^{-1}$. Instrument control, data acquisition and processing were performed using MSD Chemstation (Rev E02.00) (Agilent Technologies, Mulgrave, Australia) [15].

\section{Results and discussion}

\subsection{The condition of cement mortar lining deterioration}

\subsubsection{XRD analysis of compositions of cement mortar lining}

X-ray diffraction analysis (XRD) analysis of cementmortar liner samples (Table 4) showed that the content of $\mathrm{CaCO}_{3}$ in all the samples obviously increased with the experimental time prolonging. However, the hydration products of cement: Portlandite $\left(\mathrm{Ca}(\mathrm{OH})_{2}\right)$, Calcium Silicate $\left(\mathrm{Ca}_{3} \mathrm{SiO}_{5}\right.$, abbrev. $\left.\mathrm{C}_{3} \mathrm{~S}\right)$, Larnite $\left(\mathrm{Ca}_{2} \mathrm{SiO}_{4}\right.$, abbrev. $\left.\mathrm{C}_{2} \mathrm{~S}\right)$, Brownmillerite $\left(\mathrm{Ca}_{2}\left(\mathrm{Al}, \mathrm{Fe}^{3+}\right)_{2} \mathrm{O}_{5}\right)$ and Tricalcium aluminate $\left(\mathrm{Ca}_{3} \mathrm{Al}_{2} \mathrm{O}_{6}\right.$, abbrev. $\left.\mathrm{C}_{3} \mathrm{~A}\right)$ had gradually decreased contents. When the experiment was carried out to the 296 days and the 564 days, all the crystalline materials in the SL samples were $\mathrm{CaCO}_{3}$ because of the carbonation reaction. Calcium which escaped from the hydration products of cement-mortar reacted with $\mathrm{CO}_{3}{ }^{2-}$ or $\mathrm{HCO}^{3-}$ in water leading to deterioration of the cement material. A large amount of white materials deposited on the surface of the lining in the day 296 were crystalline composition: $\mathrm{CaSO}_{4} \cdot 2 \mathrm{H}_{2} \mathrm{O}$, $\mathrm{CaAl}_{2} \mathrm{Si}_{2} \mathrm{O}_{8} \cdot 4 \mathrm{H}_{2} \mathrm{O}$ and $\mathrm{Mg}_{4} \mathrm{Al}_{2}(\mathrm{OH})_{14} \cdot 3 \mathrm{H}_{2} \mathrm{O}$. These materials generated by the dissolved $\mathrm{Ca}, \mathrm{Si}, \mathrm{Al}$ and $\mathrm{Mg}$ minerals in hydration products were unstable and they had low strength. 


\subsubsection{XRF analysis of compositions of cement mortar lining}

Table 3 shows that in the day 296 the results of the XRF analysis of the skin samples with the thickness of 2-3mm on the cement mortar lining surface and the remaining internal samples. From this result, it can be found that the content of $\mathrm{Ca}$ in the lining skin sample is higher than that in the inner layer sample in the day 296, but the contents of major elements of the surface layer sample such as $\mathrm{Si}, \mathrm{Al}, \mathrm{Mg}$ and $\mathrm{Fe}$ are lower than those in the inner layer sample. Cement mortar specimens were eroded by chemical and microbial factors of water quality, so the main elements reduced and the elements of reduced contents lost into water.According to the results of XRD analysis, all the main crystalline materials in the inner surface samples are $\mathrm{CaCO}_{3}$. But the XRF results show that there are amorphous minerals containing $\mathrm{Si}, \mathrm{Al}, \mathrm{Mg}, \mathrm{Fe}$ and other elements in the surface layer. The previous cement hydration products changed into these minerals after the lining suffering erosion.

Table 3. XRF Semi-quantitative Analysis of the main elements in the Surface and Inner of cement lining samples.

\begin{tabular}{ccc}
\hline Sample ID & Element & Relative percentage \% \\
\hline & $\mathrm{Ca}$ & 72.94 \\
& $\mathrm{Si}$ & 9.23 \\
& $\mathrm{Al}$ & 3.85 \\
& $\mathrm{Mg}$ & 3.50 \\
Surface & $\mathrm{Fe}$ & 3.35 \\
-296d & $\mathrm{S}$ & 3.70 \\
& $\mathrm{Ti}$ & 0.64 \\
& $\mathrm{Zn}$ & 0.96 \\
& $\mathrm{Na}$ & 0.73 \\
& $\mathrm{~K}$ & 0.83 \\
& $\mathrm{Mn}$ & 0.27 \\
\hline & $\mathrm{Ca}$ & 65.76 \\
& $\mathrm{Si}$ & 16.66 \\
& $\mathrm{Al}$ & 5.75 \\
& $\mathrm{Mg}$ & 4.19 \\
Inner layer & $\mathrm{Fe}$ & 2.85 \\
-296d & $\mathrm{S}$ & 1.25 \\
& $\mathrm{Ti}$ & 1.52 \\
& $\mathrm{Zn}$ & 0.66 \\
& $\mathrm{Na}$ & 0.57 \\
& $\mathrm{~K}$ & 0.41 \\
& $\mathrm{Mn}$ & 0.37 \\
\hline
\end{tabular}

\subsection{Microbial biomass of simulate reclaimed water network and changes in related indicators of water quality}

The Total DAPI counts showed that the microbial biomass of the reclaimed water in system had been rising slowly during the 1 year-experiment due to no disinfectant added (Fig. 2A). Microbiological growth curve of the effluent water of simulate RWDS (Fig. 2B) shows that the microorganism undergone a acclimation phase, logarithmic growth phase, stationary phase and endogenous respiration phase within a month. High nutrients and organic matter levels in combination with low chlorine residuals in reclaimed water initiate bacterial growth in the RWDS. Both the SL and IL samples contained high percentage of sulfur elements indicated by XRF analysis, which confirmed the biological activity of the sulfur related bacteria (SOB/SRB).

\subsection{GC-MS analysis of microbial metabolites}

GC-MS showed that the majority of the metabolites identified were a combination of fatty acids, amino acids and carbohydrates. The organic acids mainly included undecanoic acid, hexadecanoic acid, octadecanoic acid, fatty acid 16 : 0 , lactic acid, oxalic acid, octadecenoic acid, myristic acid, adipic acid, pelargonic acid, etc. Non-organic acid materials mainly included glucose, fructose, glycerin, urea, pyroglutamic acid, putrescine, etc. Organic acids in microbial metabolites can react with cement hydration products $\mathrm{Ca}(\mathrm{OH})_{2}$ and $\mathrm{CSH}$ forming soluble substances or gypsum, which could result to the deterioration of cement materials.

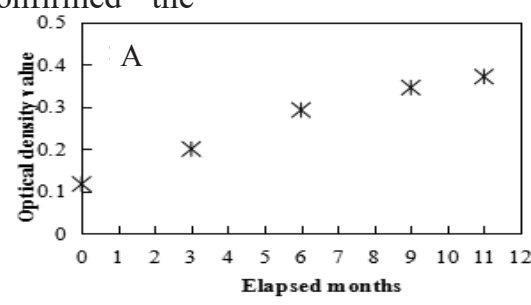

* Corresponding author:fanyang20062800@163.com 


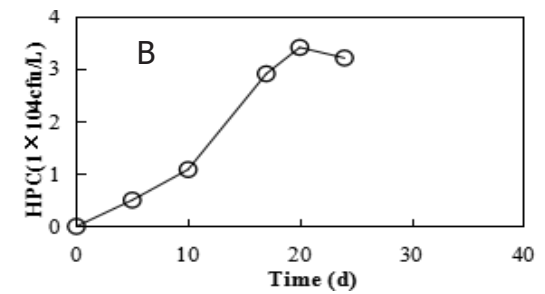

Fig.2. Variation curve of effluent microbial biomass : total DAPI counts (A ) and Heterotrophic plate counts (HPC) (B)

\section{Conclusion}

$\mathrm{XRD}$ and XRF analysis results showed that reclaimed water had strong chemical and microbiological attack on cement-mortar lining. Reclaimed water had lower $\mathrm{pH}$ than of that of cement-mortar lining. A calcium carbonate deposit was formed on the liner surface because of the carbonation reaction of $\mathrm{Ca}(\mathrm{OH})_{2}$ and $\mathrm{CSH}$ in cement-mortar, and $\mathrm{Ca}, \mathrm{Si}, \mathrm{Al}, \mathrm{Mg}$ and other elements in cement hydration products also diffused into the transported water due to erosion. Nitrification of microorganisms in the lining biofilm reduced the $\mathrm{pH}$ of the interface and promoted the erosion reaction. The metabolites of microorganisms mainly included fatty acids, amino acids and carbohydrates. Organic acids can react with cement hydration products and result to the deterioration of cement material. Therefore, the use of effective disinfectants to inhibit microbial regrowth and improve the physicochemical property of cement-mortar lining for better corrosion resistance must be employed to maintain the operational safety in recycled water distribution system.

\section{Funding information}

This work was financially supported by National Natural Science Foundation of China (No. 51308392). Also, the project was funded by the Research Fund of Tianjin Key Laboratory of Aquatic Science and Technology. The funders had no role in study design, data collection and interpretation, or the decision to submit the work for publication.

\section{References}

1. F. Teng, Y.T. Guan, W.P. Zhu, Corros. Sci., 50, 2816-2823 (2008)

2. H.B. Wang, H. Chun, X.X. Hu, M. Yang, J.H. Qu, Water Res., 46, 1070-1078 (2012)
3. P. Sarin, V.L. Snoeyink, J. Bebee, K.K. Jim, M. A. Beckett, W.M. Kriven, J.A. Clement, Water Res., 38, 1259-1269 (2004)

4. J.T. Jin, G.X. Wu, Y.T. Guan, Water Res., 71, $207-$ 218 (2015)

5. P. Leroy, M.R. Schock, I. Wagner, H. Holtschulte, Cement-Based Materials. In Internal Corrosion of Water Distribution Systems. Cooperative Research Report. AWWA Research Foundation, Denver, CO, 313-388 (1996)

6. J. Monteny, E. Vincke, A. Beeldens, N.D. Belie, L. Taerwe, D.V. Gemert, W. Verstraete, Cem. Concr. Res., 30, 623-634 (2000)

7. R.P. George, V. Vishwakarma, S.S. Samal, U.K. Mudali, Concrete Research Letters, 3, 491-506 (2012)

8. Y.Yang, Study on the effective of water quality and hydraulic characteristics on the erosiveness of pipe inner wall for the distribution systems of reclaimed water. Xi'an University of Architecture and Technology, Xi'an, China, (2012)

9. J.T. Jin , G.X. Wu, Z.H. Zhang, Y.T. Guan, Bioresour. Technol., 165, 162-165 (2014)

10. L.S. Clesceri, A.E. Greenberg, A.D. Eaton, Standard method for the examination of water and wastewater. American Public Health Association, Washington, DC (1999)

11. F.H. Chung, J. Appl. Crystallogr., 8, 17-19 (1975)

12. M. Batté, L. Mathieu, P. Laurent, M. Prévost, Can. J. Microbiol., 49, 741-753 (2003)

13. H.S. Kim, P.R. Jaffé, water res., 41, 2089-2100 (2007)

14. G. Guibaud, N. Tixier, A. Bouju, M. Baudu, Chemosphere. 52, 1701-1710 (10)

15. D. J. Beale, M. S. Dunn, Corros. Sci., 55, 272-279 (2012) 